\title{
Priming the (Proton) Pump
}

\author{
Jonathan D. Kaunitz
}

Published online: 14 March 2014

(C) Springer Science+Business Media New York (Outside the USA) 2014

For me, I am driven by two main philosophies: know more today about the world than I knew yesterday and lessen the suffering of others. You'd be surprised how far that gets you.

Neil deGrasse Tyson

In the long history of humankind (and animal kind, too) those who learned to collaborate and improvise most effectively have prevailed.

Charles Darwin

You can observe a lot just by watching.

Yogi Berra

With these quotations, I would like to introduce the fourth installment of the "Paradigm Shifts in Perspective" series, which features a personal retrospective by George Sachs, one of the most prominent clinician-investigators in the quest to discover effective gastric antisecretory drugs.

Fewer physicians each year recall the scourge that was peptic ulcer disease prior to the advent of today's antisecretory therapy. As a GI fellow in 1979, much of our training was geared toward recognizing and treating the morbid effects of peptic ulcer surgery and the use of antacids and diets to treat ulcers. The "antisecretory era" started with the original report of the $\mathrm{H}_{2}$ receptor antagonist metiamide in 1973 by Nobel Laureate James Black [1], clinical approval of cimetidine in the UK in 1976, the initial report of the antisecretory properties of the original

J. D. Kaunitz $(\square)$

West Los Angeles VAMC and Departments of Medicine and Surgery, UCLA School of Medicine, 11301 Wilshire Blvd, Bldg 114, Room 217E, Los Angeles, CA 90073, USA

e-mail: jake@ucla.edu proton pump inhibitor (PPI) omeprazole published in 1981 [2], culminated by the approval of omeprazole in 1989.

Antisecretory drugs have revolutionized the treatment of acid-peptic disease, with the near abolition of surgical peptic ulcer treatments [3] and the effective treatment of reflux-related mucosal injury and symptoms. Although adverse effects of PPIs have received much attention in the lay press and in the medical literature, the frequency of and magnitude of these effects are quite low relative to the hundreds of millions of doses taken [4, 5]. Indeed, PPIs are one of the greatest advances to our field of gastroenterology in the second half of the twentieth century and arguably one of the paramount developments in all of medicine during that period.

In the accompanying article, George Sachs (Fig. 1) spins a personal, compelling, fascinating, and insightful glimpse into the world from which antisecretory drugs emerged. Dr. Sachs first described the correct mechanism of $\mathrm{H}^{+}$secretion by the gastric $\mathrm{H}^{+}, \mathrm{K}^{+}$ATPase [6], following descriptions by other scientists of its hydrolytic activity $[7,8]$. At that time, George was clearly positioned at the intersection of scientific world with his scholarly and innovative articles and the pharmaceutical world in which he interacted freely with the scientists and management of SmithKline, which developed cimetidine, and Astra AB, which developed omeprazole. George's considerable scientific acumen, keen perspective, and quick mind enabled him to convince Astra to develop omeprazole clinically, claiming that its sales would exceed \$US $1 \mathrm{bn}$. How wrong he was, since the annual worldwide sale of PPIs has exceed \$US 20 bn in the last 10 years, with cumulative sales since approval in 1989 likely exceeding \$US 400 bn. [9]. In terms of scientific impact, over 30,000 articles have been published about PPIs and over 10,000 about the gastric proton pump since their original descriptions, a paradigm 


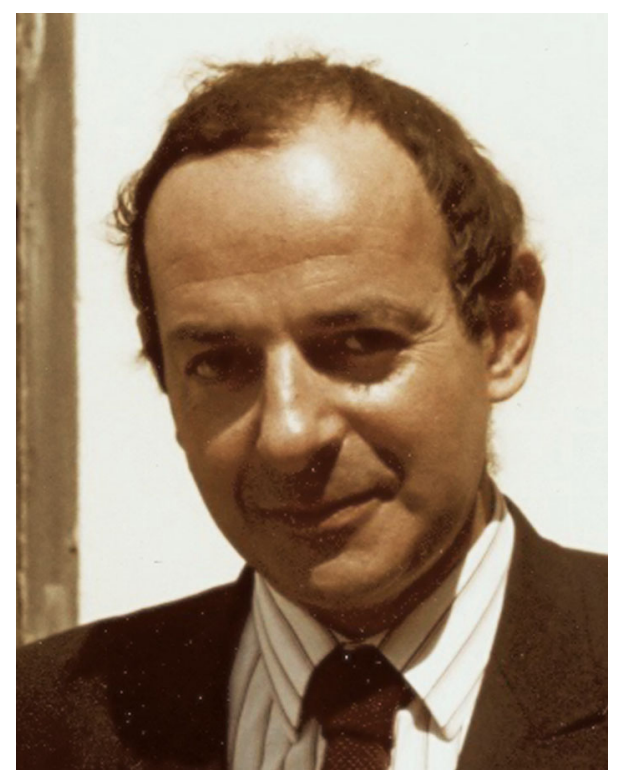

Fig. 1 George Sachs, c. 1975 (photo courtesy of Dr. Sachs)

shift indeed. I was fortunate to be a member of Dr. Sachs' laboratory in the heady days of the early 1980s just after the discovery of omeprazole, when much of the work on its antisecretory mechanism was underway. This understanding of omeprazole's mechanism-of-action was quickly translated into the pre-prandial dosing regimen still in use and also provided a plausible explanation for the precise targeting of PPIs to the secretory canaliculus of the parietal cell, explaining the class' overall safety.

Dr. Sachs, after describing his involvement with the development and of antisecretory drugs, then describes an important use for PPIs, namely in the eradication of Helicobacter pylori, the causative organism for peptic ulceration, the discovery of which was described in a previous article in this series [10].

The only feat superior to making a significant discovery is to witness its impact during one's lifetime. Dr. Sachs has certainly "lessened the suffering of others" by learning to "collaborate and improvise" and by "observing," a tribute not only to his exceptional scientific gift but also to the atmosphere of the 1980s, with increasing amounts of funding supporting basic research combined with relatively unfettered relations between academia and pharma. Since innovation flourishes when information flows freely, a look back to that era as Dr. Sachs has done provides a poignant and nostalgic glimpse into a vanished realm where investigators spent most of their day thinking, talking, and doing science rather than by filling out paperwork. We are all beneficiaries of George's creativity and foresight; let us hope that others will come along who can effect similar breakthroughs.

\section{References}

1. Black JW, Duncan WA, Emmett JC, et al. Metiamide - an orally active histamine $\mathrm{H}_{2}$-receptor antagonist. Agents Actions. 1973;3: 133-137.

2. Fellenius E, Berglindh T, Sachs G, et al. Substituted benzimidazoles inhibit gastric acid secretion by blocking $\left(\mathrm{H}^{+}+\mathrm{K}^{+}\right)$ATPase. Nature. 1981;290:159-161.

3. Lagoo J, Pappas TN, Perez A. A relic or still relevant: the narrowing role for vagotomy in the treatment of peptic ulcer disease. Am J Surg. 2014;207:120-126.

4. Fashner J, Gitu AC. Common gastrointestinal symptoms: risks of long-term proton pump inhibitor therapy. FP Essent. 2013;413: 29-39.

5. Johnson DA, Oldfield EC IV. Reported side effects and complications of long-term proton pump inhibitor use: dissecting the evidence. Clin Gastroenterol Hepatol. 2013;11:458-464.

6. Sachs G, Chang HH, Rabon E, Schackman R, Lewin M, Saccomani G. A nonelectrogenic $\mathrm{H}^{+}$pump in plasma membranes of hog stomach. J Biol Chem. 1976;251:7690-7698.

7. Mózsik G, Nagy L, Tárnok F, Vizi F, Kutas J. $\mathrm{H}^{+}$secretion and $\mathrm{Na}^{+}-\mathrm{K}^{+}$-dependent ATPase system in the human gastric mucosa. Experientia. 1974;30:1024-1025.

8. Forte JG, Ganser A, Beesley R, Forte TM. Unique enzymes of purified microsomes from pig fundic mucosa. $\mathrm{K}^{+}$-stimulated adenosine triphosphatase and $\mathrm{K}^{+}$-stimulated pNPPase. Gastroenterology. 1975;69:175-189.

9. http://www.imshealth.com/deployedfiles/imshealth/Global/Content/ StaticFile/Top_Line_Data/Global_Top_15_Therapy_Classes.pdf

10. Moss SF. The rediscovery of $\mathrm{H}$. pylori bacteria in the gastric mucosa by Robin Warren, and implications of this finding for human biology and disease. Dig Dis Sci. 2013;58:3072-3078. 